\title{
PENGEMBANGAN EKOWISATA DI KAWASAN WISATA PERKEBUNAN KOPI DI DESA KARE KECAMATAN KARE KABUPATENMADIUN
}

\author{
ECO TOURISM DEVELOPMENT IN THE COFFEE PLANTATION TOURISM \\ AREA IN KARE VILLAGE, KECAMATAN KARE, MADIUN DISTRICT
}

\author{
Julieta Kartikasari ${ }^{1}$, Kirana Anugerah Putri ${ }^{2}$, Radicha Arnanda Putri Indrawati ${ }^{3}$, \\ Veren Audia Nurmansya ${ }^{4}$, dan Wulandari Prima Devi ${ }^{5}$, Bella Wahyu Sukma \\ Wati $^{6}$, Sherina Pradita Eka Wahyudi ${ }^{7}$, Fa'ilal Chusna ${ }^{8}$, Nabila Safira Khirina', \\ Tria Refi Indriani ${ }^{10}$, Cindy Narita Kusuma Astuti ${ }^{11}$, Prihartini Widiyanti ${ }^{12}$
}

\author{
7,8,11 Program Studi Kebidanan, Fakultas Kedokteran \\ 1,2,3 Program Studi Ekonomi Pembangunan, Fakultas Ekonomi dan Bisnis \\ 6,10 Program Studi Akuntansi, Fakultas Ekonomi dan Bisnis \\ 4,5 Program Studi Fisika, Fakultas Sains dan Teknologi \\ 9 Program Studi Kesehatan Masyarakat, Fakultas Kesehatan Masyarakat \\ ${ }^{12}$ Departemen Fisika, Fakultas Sains dan Teknologi \\ *email: julieta.kartikasari-2018@feb.unair.ac.id
}

\begin{abstract}
IPE 63 Community Service Activities (KKN) Group 179 Airlangga University in Kare Coffee Tourism, Kare Village, Kare District, Madiun City, with the theme of ecotourism which was held on19 January 2021 to 13 February 2021 aimed at developing curry coffee tourism areas, increasing public awareness of health and providing health facilities in accordance with health protocols, attracting tourists through promotions on various social media, adding insight into how to utilize coffee processing waste so that it can be of economic value. as well as coffee cultivation techniques and ways to increase coffee production for coffee entrepreneurs and producers in Kare village. As for the design of activities carried out in the form of procurement of complete tourist facilities and procurement of complete protocol facilities that are not yet available in Kare Coffee tours and their availability is needed, by purchasing goods online and sending items that have been purchased directly to Kare Village. Promotion of curry coffee tourism, by utilizing existing social media such as Instagram and YouTube by uploading a coffee tour profile video so that it can be known to the wider community and can attract both local and international tourists. The use of coffee waste, by providing education and training to the community in Kare Village, is carried out online as well as uploading the video of the seminar results to YouTube regarding the utilization of coffee waste carried out online and uploading the seminar results video to YouTube. And webinars on ecotourism, CHSE protocols, coffee cultivation techniques, and increased coffee production were conducted online on the same day then uploaded the webinar results to Youtube.
\end{abstract}

Keywords: Coffee, Health Protocol, Travel

10.20473/jlm.v5i1.2021.177-184

Open acces under CC BY-SA license

Creative Commons Attribution-ShareAlike 4.0 International License 


\begin{abstract}
Abstrak
Kegiatan Kuliah Kerja Nyata (KKN) IPE 63 Kelompok 179 Universitas Airlangga di Wisata Kopi Kare, Desa Kare, Kecamatan Kare, Kota Madiun, dengan tema ekowisata yang dilaksanakan pada tanggal 19 Januari 2021 hingga 13 Februari 2021 bertujuan untuk mengembangkan kawasan wisata kopi kare, meningkatkan kesadaran masyarakat akan kesehatan dan memberikan fasilitas kesehatan yang sesuai dengan protokol kesehatan, menarik minat wisatawan melalui promosi di berbagai media sosial, menambah wawasan tentang cara memanfaatkan limbah pengolahan kopi agar dapat bernilai ekonomis. serta teknik budidaya kopi dan cara meningkatkan produksi kopi kepada pengusaha dan produsen kopi di desa Kare. Adapun rancangan kegiatan yang dilakukan berupa pengadaan kelengkapan fasilitas wisata dan pengadaan kelengkapan fasilitas protokol yang sekiranya belum tersedia di wisata Kopi Kare dan dibutuhkan ketersed iaannya, dengan cara melakukan pembelian barang- barang secara online dan mengirimkan barang yang sudah dibeli langsung ke Desa Kare. Promosi wisata kopi kare, dengan memanfaatkan media sosial yang ada seperti Instagram dan youtube dengan mengunggah video profil wisata Kopi Kare agar dapat dikenal masyarakat luas serta dapat menarik wisatawan baik lokal maupun internasional. Pemanfaatan limbah kopi, dengan memberikan edukasi serta pelatihan kepada masyarakat di Desa Kare dilakukan secara daring serta mengupload video hasil seminar ke youtube terkait pemanfaatan limbah kopi dilakukan secara daring serta mengupload video hasil seminar ke youtube. Dan webinar mengenai ekowisata, protokol CHSE, teknik budidaya kopi, dan peningkatan produksi kopi yang dilakukan secara daring pada hari yang sama kemudian mengunggah hasil webinar ke Youtube.
\end{abstract}

Kata kunci : Kopi, Protokol Kesehatan, Wisata

\title{
PENDAHULUAN
}

Ecotourism atau ekowisata adalah salah satu kegiatan yang berwawasan dengan mengutamakan aspek konservasi alam, aspek pemberdayaan sosial budaya ekonomi masyarakat lokal serta aspek pembelajaran dan pendidikan. Ekowisata adalah perjalanan yang bertanggung jawab ke daerah-daerah alami yang melestarikan lingkungan, menopang kesejahteraan masyarakat setempat, melibatkan interpretasi serta pendidikan lingkungan hidup (The International Ecotourism Society, 2015). Pada Provinsi Jawa Timur tepatnya di Desa Kare, Kecamatan Kare, Kabupaten Madiun memiliki potensi sumber daya alam yang begitu melimpah. Dari sumber daya alam yang melimpah tersebut, dapat dikembangkan menjadi tempat wisata yang tak kalah menarik dari wisata - wisata terkenal yang ada di kota. Salah satunya adalah wisata perkebunan kopi kare. Potensi kebun kopi di Desa Kare dapat dijadikan sebagai pemasaran yang sangat menjanjikan dengan mengembangkan lahan perkebunan menjadi salah satu area ekowisata (Yuhana \& Nurhikmawati , 2017). Prasyarat utama agar aset yang cukup berharga tersebut dapat menjadi sebuah komoditas daerah adalah dikelolanya potensi daerah tersebut dengan baik sesuai standar minimal industri pariwisata (Arifin \& Ariyanto, 2018). Adanya area ekowisata diharapkan dapat meningkatkan pengembangan kopi kare sehingga potensi kopi di daerah tersebut dapat dikenal lebih luas dan menjadi ikon wisata di Desa Kare. Wisata kebun kopi tersebut telah dikelola oleh petani sekitar sehingga hasil dari kebun kopi tersebut dapat diproduksi menjadi bubuk dan siap dikonsumsi. Kopi produksi para petani Kare ini pun sudah memiliki brand yaitu Kopi Kare. Namun, wisata kopi kare sendiri tidak banyak diketahui keberadaanya oleh para wisatawan luar Kota Madiun. Wisata kopi kare sendiri yang diberi nama 
"Warung Kopi Kare Madiun" ini memiliki tempat seperti layaknya warung yang menjual berbagai makanan dan khususnya kopi kare itu sendiri namun tempat ini menjadi berbeda karena panorama alam yang disuguhkan di sekitar area tersebut. Keindahan alam inilah yang memicu kelompok kami untuk membantu agar Wisata Kebun Kopi Kare dapat dikenal oleh masyarakat yang ada di Kota Madiun sendiri maupun masyarakat luar Kota Madiun sendiri. Masalah lainnya adalah menurut Ketua Kelompok Tani Mugi Lestari Desa Kare, Madiun, Bapak Sumadi, mengatakan bahwa dari 55 hektare lahan kebun kopi, yang baru bisa berbuah hanya sekitar 30 hektar saja. Sedangkan yang lain belum bisa berbuah.

Menurut Philip Kotler dan Kevin Keller (2012:568) bahwa pengertian media sosial adalah sarana bagi konsumen untuk berbagai informasi teks, gambar, video, dan audio dengan satu sama lain dan dengan perusahaan dan sebaliknya. Menurut hasil riset oleh 'We Are Social' diantara banyaknya jenis media sosial, media sosial yang diminati orang Indonesia saat ini diantaranya Youtube, Facebook, Instagram, dan Twitter. Ekowisata adalah perjalanan yang bertanggung jawab ke daerah-daerah alami yang melestarikan lingkungan, menopang kesejahteraan masyarakat setempat, melibatkan interpretasi serta pendidikan lingkungan hidup (The International Ecotourism Society, 2015). Potensi kebun kopi di Desa Kare dapat dijadikan sebagai pemasaran yang sangat menjanjikan dengan mengembangkan lahan perkebunan menjadi salah satu area ekowisata (Yuhana \& Nurhikmawati , 2017). Prasyarat utama agar aset yang cukup berharga tersebut dapat menjadi sebuah komoditas daerah adalah dikelolanya potensi daerah tersebut dengan baik sesuai standar minimal industri pariwisata (Arifin \& Ariyanto, 2018). Protokol kesehatan disahkan melalui KMK Nomor HK.01.07/Menkes/382/2020 tentang Protokol Kesehatan Bagi Masyarakat di Tempat dan Fasilitas Umum Dalam Rangka Pencegahan dan Pengendalian Corona Virus Disease 2019 (Kompas.com,2020).

Berdasarkan informasi yang dimuat dalam wartakota, Indonesia merupakan komunitas pengguna Instagram terbesar di Asia Pasifik dengan jumlah pengguna aktifnya mencapai 45 juta orang dari total pengguna global yang berjumlah 700 juta orang. Sehingga dari adanya media sosial ini dapat menarik wisatawan luar kota agar dapat mengetahui Wisata Kopi Kare, kelompok kami melakukan promosi wisata dengan membuat video profil Wisata Kopi Kare, membuat akun media sosial untuk mendukung promosi Wisata Kopi Kare serta penyebaran pamflet. Kelompok kami juga mengadakan kelengkapan fasilitas wisata sebagai penunjang kenyamanan pengunjung dan menambah daya tarik wisata. Dalam situasi Pandemi Covid - 19 Pemerintah RI secara resmi telah mengesahkan protokol kesehatan di sektor pariwisata dan ekonomi kreatif (parekraf). Protokol tersebut disusun oleh Kemenparekraf bersama para pemangku kepentingan, serta kementerian terkait. Protokol juga disahkan melalui Keputusan Menteri Kesehatan (KMK). Protokol kesehatan disahkan melalui KMK Nomor HK.01.07/Menkes/382/2020 tentang Protokol Kesehatan Bagi Masyarakat di Tempat dan Fasilitas Umum Dalam Rangka Pencegahan dan Pengendalian Corona Virus Disease 2019 (Kompas.com,2020). Dengan diberlakukannya protokol kesehatan ini membuat kelompok kami menciptakan wisata kopi kare yang dilengkapi dengan protokol kesehatan dengan cara meningkatkan kesadaran kebersihan lingkungan dan kesehatan agar para warga sekitar serta pengunjung kebun kopi di Desa Kare, Kecamatan Kare, Kabupaten Madiun, dapat selalu menerapkan protokol kesehatan dengan baik. Selain itu, untuk menangani permasalahan selanjutnya kami juga membuat suatu webinar mengenai pengenalan ekowisata, protokol CHSE, teknik budidaya kopi dan peningkatan produksi kopi yang 
ditujukan kepada pengusaha warung kopi dan produsen kopi. Serta secara terpisah kami juga membuat video mengenai pengelolaan atau pemanfaatan limbah kopi menjadi lilin kopi dan pupuk kompos.

Kegiatan kuliah kerja nyata di Kebun Kopi Kare, Desa Kare, Kecamatan Kare, Kota Madiun memiliki tujuan : (1) Untuk mengembangkan kawasan wisata kopi kare dengan mengadakan kelengkapan fasilitas wisata sebagai penunjang kenyamanan pengunjung dan menambah daya Tarik wisata. (2) Meningkatkan kesadaran masyarakat akan kesehatan dan memberikan fasilitas kesehatan yang sesuai dengan protokol kesehatan. (3) Meningkatkan daya tarik wisatawan dengan cara menyebarkan keindahan kebun kopi kare melalui berbagai media sosial. (4) Mengajarkan pada pengusaha warung kopi dan produsen kopi bubuk di Desa Kare terkait cara memanfaatkan limbah dari pengolahan kopi sehingga dapat dijadikan sebuah produk baru yang bernilai ekonomis. (5) Menambah wawasan mengenai Teknik budidaya kopi dan cara meningkatkan produksi kopi kepada pengusaha kopi dan produsen kopi.

Dengan adanya rangkaian kegiatan tersebut diharapkan dapat meningkatkan jumlah wisatawan dari dalam maupun dari luar kota Madiun yang tertarik untuk berkunjung ke Wisata Kopi Kare dan mengetahui adanya produk kopi khas daerah Desa Kare itu sendiri. Dari banyaknya wisatawan yang berkunjung tentunya dapat merasa lebih aman di masa pandemi ini karena telah diberlakukannya protokol kesehatan dengan fasilitas penunjang protokol kesehatan. Diharapkan dengan adanya webinar yang telah dibuat dapat menambah wawasan bagi para produsen kopi di Desa Kare agar menghasilkan kopi yang berkualitas baik bagi konsumen.

\section{METODE PENGABDIAN MASYARAKAT}

Melalui kegiatan Kuliah Kerja Nyata (KKN) IPE 63 Kelompok 179 Universitas Airlangga di Wisata Kopi Kare, Desa Kare, Kecamatan Kare, Kota Madiun, memiliki rancangan kegiatan berupa pengadaan kelengkapan fasilitas wisata, pengadaan kelengkapan fasilitas protokol kesehatan, promosi wisata kopi kare, pemanfaatan limbah kopi, dan webinar mengenai ekowisata, protokol CHSE, teknik budidaya kopi, dan peningkatan produksi kopi. Untuk menarik wisatawan luar kota, kelompok kami melakukan promosi wisata dengan mengunggah video profil Wisata Kopi Kare pada laman youtube KKN IPE 63 KELOMPOK 179 dan juga membuat akun media sosial Instagram dengan nama akun@kkn.kopikare untuk mendukung promosi Wisata Kopi Kare serta penyebaran pamflet pada akun media sosial instagram masing masing anggota kelompok kami yang terdiri dari 11 orang. Kelompok kami juga mengadakan kelengkapan fasilitas wisata sebagai penunjang kenyamanan pengunjung dan menambah daya tarik wisata seperti membuat dan mencetak mading, booklet wisata, tiket masuk untuk wisatawan dan juga banner. Yang nantinya hasil cetakan tersebut akan dikirimkan ke alamat Wisata Kebun Kopi Kare, Desa Kare, Kecamatan Kare, Kota Madiun. Dengan diberlakukannya protokol kesehatan pada daerah wisata, maka kelompok kami menyiapkan fasilitas protokol kesehatan berupa satu set tempat cuci tangan, sabun, hand sanitizer, poster himbauan protokol kesehatan, masker serta thermogun untuk Wisata Kopi Kare dengan mengirimkan barang - barang tersebut ke alamat Wisata Kebun Kopi Kare, Desa Kare, Kecamatan Kare, Kota Madiun. Selain itu, untuk meningkatkan kesadaran kebersihan lingkungan dan kesehatan bagi masyarakat Desa Kare kelompok kami membuat suatu video protokol kesehatan mengenai vaksinasi Covid -19 . Video tersebut diunggah pada laman youtube KKN IPE 
63 KELOMPOK 179 yang linknya dibagikan melalui grup whatsapp dimana anggotanya terdiri dari warga Desa Kare.

Untuk menambah wawasan pengusaha warung kopi dan produsen kopi bubuk di Desa Kare, kami telah membuat video singkat mengenai pemanfaatan limbah kopi menjadi lilin kopi dan pupuk kompos yang telah diunggah pada laman youtube KKN IPE 63 KELOMPOK 179 yang linknya dibagikan melalui grup whatsapp dimana anggotanya terdiri dari pengusaha warung kopi dan produsen kopi bubuk dan warga Desa Kare. Selain itu, kami juga menyelenggarakan webinar melalui zoom mengenai materi ekowisata, protokol CHSE, Teknik budidaya kopi dan peningkatan produksi kopi yang dapat diakses oleh warga Desa Kare yang link zoomnya sendiri telah dibagikan pada grup whatsapp satu hari sebelumnya.

\section{HASIL DAN PEMBAHASAN}

Dalam rangka pengembangan Ekowisata Kopi Kare yang terletak di kawasan Madiun lebih tepatnya di Desa Kare, Kecamatan Kare, Kabupaten Madiun, Provinsi Jawa Timur ini, yang memiliki potensi yang sangat besar jika ekowisata ini dapat dimanfaatkan secara maksimal. Adapun rincian kegiatan yang dilakukan adalah sebagai berikut. (1) Webinar Pengembangan Ekowisata Kopi Kare. Kegiatan ini dilaksanakan dalam rangka mendukung potensi pengembangan kopi kare yang mana bertujuan untuk membantu mengusulkan langkah- langkah yang dapat ditempuh dalam pengembangan kopi kare itu sendiri. Webinar ini dilaksanakan pada tanggal 31 Januari 2021 dengan sasaran pengusaha kopi di daerah kawasan Kopi Kare. Dalam webinar yang kami adakan ada beberapa poin penting yang disampaikan antara lain penjelasan mengenai Ekowisata, Protokol CHSE, Teknik Budidaya, dan Peningkatan Produksi Kopi. (2) Penyuluhan Vaksinasi. Kegiatan ini dilakukan dengan memberikan edukasi terkait teknik vaksinasi mengingat kondisi pandemi yang sangat tidak pasti seperti saat ini. Tujuan dari diadakannya penyuluhan vaksinasi ini sendiri adalah untuk meningkatkan pengetahuan masyarakat di Desa Kare. Acara penyuluhan vaksinasi ini dilakukan pada tanggal 1 Februari 2021 dengan sasaran masyarakat di Desa Kare. Dalam terlaksananya penyuluhan vaksinasi ini, kami membuat video dan mengunggahnya ke youtube untuk mempermudah warga yang menjadi sasaran untuk mengakses edukasi penyuluhan vaksinasi. (3) Pemanfaatan Limbah Kopi. Kegiatan ini dilakukan dengan memberikan edukasi serta pelatihan kepada masyarakat di Desa Kare terkait pemanfaatan limbah kopi yang sudah tidak terpakai seperti ampas kopi dan kulit buah kopi untuk dimanfaatkan menjadi produk baru seperti lilin kopi dan kompos kopi. Tujuan dari adanya penyuluhan mengenai pemanfaatan limbah kopi ini diantaranya adalah mengajarkan pada pengusaha warung kopi serta produsen kopi bubuk di Desa Kare terkait cara memanfaatkan limbah dari pengolahan kopi, seperti ampas kopi dan kulit buah kopi, sehingga bisa dijadikan sebuah produk baru yang bernilai ekonomi. Kegiatan ini dilakukan pada tanggal 5 Februari 2021 dengan sasaran pengusaha warung kopi, produsen kopi bubuk di Desa Kare, serta masyarakat di Desa Kare dan di luar di Desa Kare. Adapun pelaksanaan penyuluhan mengenai pemanfaatan limbah kopi ini dilakukan secara daring serta mengupload video hasil seminar ke youtube agar mudah diakses kembali oleh sasaran yang dimaksud. (4) Promosi Wisata Kopi Kare. Kegiatan ini merupakan promosi dengan memanfaatkan media sosial yang ada, seperti Instagram dan youtube yang harapannya wisata kopi kare ini dapat dikenal masyarakat luas serta dapat menarik wisatawan 
baik lokal maupun internasional. Kegiatan promosi wisata Kopi Kare ini dilakukan pada tanggal 1

Februari 2021 dengan sasaran masyarakat di luar Desa Kare. Kegiatan ini kami lakukan dengan cara

mengupload video profil Wisata Kopi Kare dan iklan melalui Youtube dan Instagram. (5) Pengadaan Fasilitas Wisata dan Protokol Kesehatan. Kegiatan ini dilakukan dengan melakukan kelengkapan fasilitas wisata dan fasilitas protokol kesehatan yang sekiranya belum tersedia di wisata Kopi Kare dan dibutuhkan ketersediaannya. Tujuan dari diadakannya pengadaan fasilitas wisata dan protokol kesehatan ini adalah menambah adanya fasilitas yang mendukung keindahan wisata dan penerapan protokol kesehatan baik dari warga Desa Kare maupun pengunjung di Desa Kare. Kegiatan ini dilaksanakan pada tanggal 8 Februari 2021 dengan sasaran pengadaan fasilitas di Wisata Kopi Kare. Kegiatan ini kami lakukan dengan cara melakukan pembelian barang- barang secara online dan mengirimkan barang yang sudah dibeli langsung ke Desa Kare.

Penerapan protokol kesehatan berbasis CHSE (Cleanliness, Health, Safety and Environment Sustainability) adalah penerapan protokol kesehatan dengan beberapa kriteria diantaranya, (1) Cleanliness. Pada aspek kebersihan, secara umum pelaku usaha harus memastikan kebersihan pada tempat usahanya, seperti ketersediaan sabun cuci tangan atau hand sanitizer untuk pengunjung. Memastikan tempat usaha selalu bersih, baik dari kuman, bakteri, maupun virus dengan penyemprotan disinfektan juga merupakan syarat dalam memenuhi aspek ini. (2) Health. Dalam menjaga kesehatan di area usaha, pelaku usaha perlu menjaga kesehatan baik para pekerja maupun pengunjung. Mulai dari pengecekan suhu tubuh, pemakaian masker, hingga menerapkan pembatasan sosial dengan pengaturan jarak serta meminimalisasi kerumunan. (3) Safety. Untuk menjaga keamanan serta keselamatan, pelaku usaha perlu menyiapkan prosedur penyelamatan apabila sewaktu-waktu terjadi bencana atau kondisi darurat yang tidak diinginkan. Hal ini bertujuan untuk menjamin keselamatan orang-orang yang berada dalam area tersebut. (4) Environment Sustainability. Pelaku usaha perlu memastikan bahwa usahanya telah menerapkan kondisi yang ramah lingkungan. Misalnya saja dengan penggunaan perlengkapan dan bahan ramah lingkungan, hingga mengkondisikan area agar terasa nyaman untuk pengunjung.

Tabel 1. Indikator Keberhasilan dan Realisasi Indikator Keberhasilan

\begin{tabular}{|c|c|c|}
\hline Ind ikator & Target & Cara pengukuran \\
\hline
\end{tabular}

\begin{tabular}{|c|c|c|c|}
\hline Jumlah peserta & $\begin{array}{l}\text { Minimal terdapat } 30 \text { orang } \\
\text { bergabung di kegiatan } \\
\text { kkn kelompok } \\
179 \text { melalui zoom }\end{array}$ & $\begin{array}{l}\text { Melalui penyuluhan secara langsung } \\
\text { dengan zoom dan membuat video } \\
\text { tentang pemanfaatan limbah kopi dan } \\
\text { kesehatan. Kemudian video tersebut } \\
\text { dibagikan melalui grup whatsapp yang } \\
\text { didalam grup terdapat masyarakat } \\
\text { desa kare. }\end{array}$ & $\begin{array}{l}\text { link video } \\
\text { youtube } \\
\text { kelompok yang } \\
\text { sudah dibagikan } \\
\text { telah di lihat } 50 \\
\text { kali. }\end{array}$ \\
\hline
\end{tabular}

\section{PENUTUP}




\section{Simpulan}

Ekowisata merupakan suatu suatu pengembangan pariwisata yang mana bertujuan untuk mendukung upaya- upaya pelestarian lingkungan dan meningkatkan partisipasi masyarakat. Dalam program kerja yang telah dilakukan, terdapat upaya-upaya pemberdayaan masyarakat yang diharapkan dapat berjalan untuk kedepannya. Seperti pengolahan limbah dari ampas kopi ini dapat dilakukan oleh individu di sekitar Wisata Kopi Kare dan memberikan manfaat bagi perkebunan kopi sendiri.

Program kerja yang telah dilaksanakan juga mengupayakan adanya penerapan protokol kesehatan di tengah pandemi, khususnya pada kegiatan wisata. Protokol CHSE dirancang oleh pemerintah bagi para pengembang wisata dan protokol CHSE dapat diterapkan pada Wisata Kopi Kare. Selain itu juga terdapat program kerja penyuluhan vaksinasi yang memberikan edukasi kepada warga Desa Kare khususnya juga bagi pekerja maupun warga di sekitar Kopi Kare mengenai vaksinasi.

\section{Saran}

Beberapa saran bagi program kerja yang telah diadakan oleh Kelompok 179 pada KKN di Kopi Kare adalah sebagai berikut: (1) Program Kerja Pengadaan Fasilitas dan Kelengkapan Wisata selanjutnya dapat dilakukan secara datang langsung ke tempat wisata. Program kerja ini dapat dilakukan dengan memberikan kelengkapan wisata yang lebih lengkap seperti bangku bersantai yang berasal dari daur ulang tong bekas dan pemanfaatan barang bekas lainnya sebagai kelengkapan wisata. (2) Program kerja Webinar Protokol CHSE selanjutnya dapat dilakukan pembimbingan langsung kepada pengembang Kopi Kare dan menyampaikan secara luas kepada anggota Kopi Kare. (3) Program kerja Webinar Pengambangan Ekowisata Kopi Kare dapat dilakukan secara langsung kepada warga sekitar Desa Kare. Hal ini dilakukan karena mengingat bahwa ekowisata ini melibatkan masyarakat dalam pengembangannya. Selain itu Webinar juga dikemas secara menarik dan mudah dipahami. (4) Program kerja Promosi Wisata Kopi Kare dapat dikemas secara menarik melalui media sosial. Hal ini mengingat di tengah pandemi Covid-19 tidak diperkenankan adanya kontak fisik. Selain itu, promosi dapat memanfaatkan web blog, atau media sosial lainnya. (5) Program Kerja Pengolahan Limbah Kopi dapat dilakukan pengolahan yang lebih memanfaatkan ampas kopi hasil perkebunan. Seperti pemanfaatan kulit kopi sebagai pupuk kompos. Pupuk kompos ini dapat digunakan untuk media tanam tanaman kopi.

\section{UCAPAN TERIMA KASIH}

Kelompok 179 KKN BBM Ke-63 mengucapkan terima kasih kepada Desa Kare, Kecamatan Kare, Kabupaten Madiun sebagai tempat Kuliah Kerja Nyata dan kepada Pengembang dan warga Kopi Kare telah memberikan kami kesempatan untuk dapat belajar dan berbagi seputar Wisata Kopi Kare.

\section{DAFTAR PUSTAKA}

Btp.ac.id (2020). CHSE: Protokol Kesehatan Untuk Pariwisata dan Ekonomi Kreatif. https://btp.ac.id/protokolkesehatanchse/\#: :text=CHSE\%20adalah\%20penerapan\%20protokol\%20kesehatan,Envir onment\%20Sustainability \%20(Kelestarian\%20Lingkungan). (Diakses 14 Februari 2021) 
Purbohastuti, Arum W. 2017. Efektivitas Media Sosial Sebagai Media Promosi. Tirtayasa EKONOMIKA. 12(2) : $212-231$.

Puspitarini, Dinda S., Reni Nuraeni. 2019. Pemanfaatan Media Sosial sebagai Media Promosi (Studia Deskriptif pada Happy Go Lucky House. Jurnal Common. 3(1) : $71-80$.

Ramadhian, Nabilla. 2020. Catat, Protokol Kesehatan untuk Pengunjung Wisata, Seperti Apa? https://travel.kompas.com/read/2020/06/25/103000727/catat-protokol-kesehatanuntuk-pengunjung- tempat-wisata-seperti-apa-?page=all (Diakses 12 Februari 2021)

Solopos.com (2021). Kopi Kare, Kopi Khas Madiun Yang Ditanam dan Diproduksi Di Lerang Gunung Wilis. https://www.solopos.com/kopi-kare-kopi-khas-madiunyang-ditanam-dan-diproduksi-di-lereng-gunung- wilis-1103936 (Diakses 12 Februari 2021) 